\title{
Evaluation of loop-mediated isothermal amplification assay along with conventional and real-time PCR assay for sensitive detection of pathogenic Vibrio parahaemolyticus from seafood sample without enrichment
}

\author{
Karanth Padyana Anupama ${ }^{1}$ Ashwath Nayak ${ }^{1}$ Iddya Karunasagar ${ }^{2} \cdot$ Indrani Karunasagar $^{2} \cdot$ Biswajit Maiti $^{1}$
}

Received: 15 October 2020 / Accepted: 20 December 2020 / Published online: 9 January 2021

(c) The Author(s), under exclusive licence to Springer Nature B.V. part of Springer Nature 2021

\begin{abstract}
The primary reason for foodborne illness is improper seafood safety testing, and hence, an appropriate tool for testing is the key to control the outbreaks. The current study aimed to develop a loop-mediated isothermal amplification (LAMP) assay to detect pathogenic Vibrio parahaemolyticus, important foodborne pathogen, targeting $t d h$, and trh genes. The specificity of the LAMP assay was good without any false-positive and false-negative results. The assay was highly sensitive and could detect the pathogenic V. parahaemolyticus as low as 1 CFU/reaction in spiked seafood samples and 1 pg of extracted DNA. Out of 62 seafood samples from India's southwest coastal region tested with LAMP assay, eight (12.9\%) were positive for trh, and seven (11.29\%) samples were positive $t d h$ gene. LAMP-based on $t d h$ and $t r h$ was found to be significantly more sensitive $(p<0.05)$ than conventional PCR and nearly equal sensitive as real-time PCR (RT-PCR) for the detection of pathogenic $V$. parahaemolyticus. Our study shows that LAMP assay can be a better approach as a point-of-care (POC) diagnostic tool and could detect pathogenic V. parahaemolyticus on seafood samples directly without enrichment and isolation. The high sensitivity and simplicity make LAMP assay a better alternative method than the conventional method and RT-PCR for the detection of pathogens. LAMP assay can be considered as a good alternative to PCR for the routine detection of pathogenic V. parahaemolyticus in seafood.
\end{abstract}

Keywords LAMP assay $\cdot$ Sensitive detection $\cdot V$. parahaemolyticus $\cdot$ Without enrichment $\cdot$ Seafood

\section{Introduction}

Vibrio parahaemolyticus is a Gram-negative, halophilic bacterium, universally found in the coastal and estuarine marine waters. It is an opportunistic foodborne pathogen,

Supplementary information The online version contains supplementary material available at https://doi.org/10.1007/s1103 3-020-06116-9

Biswajit Maiti

maiti.b@nitte.edu.in

1 Nitte (Deemed to be University), Nitte University Centre for Science Education and Research (NUCSER), Division of Infectious Diseases, Paneer Campus, Deralakatte, Mangalore 575018, India

2 Nitte (Deemed to be University), University Enclave, Medical Sciences Complex, Deralakatte, Mangalore 575018, India often sheltered on marine reservoirs, predominantly in shellfish, serving as a vehicle for transmission of infection to humans, causing gastroenteritis. V. parahaemolyticus possesses different virulence properties, the major ones are thermostable direct hemolysin (TDH), and TDH-related hemolysins (TRH) encoded by $t d h$ and trh genes, respectively [1]. These factors cause hemolysis and cytotoxicity to the host cells resulting in diarrhea. The virulence genes, $t d h$, and trh are considered to be a marker for detecting pathogenic $V$. parahaemolyticus [2]. Along with these virulence genes, secretion systems also play a major role in pathogenicity (T3SS2, T3SS6) [3-5]. Reports show the involvement of adhesion factors such as $V p a d F$ as a virulence marker with the potential to be used as vaccine candidates [6]. Seafood associated disease outbreaks are one of the major threats to public health. Worldwide gastroenteritis caused by $V$. parahaemolyticus is usually due to the consumption of contaminated shellfishes and other raw or undercooked seafood. 
According to the epidemiological data, most outbreaks occur after consuming oysters and clams [7]. V. parahaemolyticus is considered to be one of the major foodborne pathogens by the Centers for Disease Control and Prevention (CDC) [8]. $V$. parahaemolyticus infection has been increased worldwide in the last two decades, including outbreaks caused by pandemic strains [9].

For the detection of V. parahaemolyticus, several methods are available from conventional to the molecular level. In general, conventional culture-based techniques are timeconsuming and often require multiple days to achieve the results. Moreover, these assays show less sensitivity when target bacteria are present in lower numbers [10]. The molecular methods include polymerase chain reaction (PCR), real-time (RT)-PCR (RT-PCR), and more advanced droplet digital PCR. However, these sophisticated techniques require expensive equipment, trained personnel, and expensive reagents [11-14]. Hence developing simple diagnostic tools without compromising simplicity and sensitivity would be very important. The loop-mediated isothermal amplification (LAMP) assay is one such method that has the potential to be a point-of-care (POC) detection tool. Recently LAMP assay has been customized and used worldwide to detect tuberculosis [15]. LAMP is a DNA based amplification method that amplifies the nucleic acid under isothermal conditions. As compared to existing molecular methods like PCR and RT-PCR, LAMP assay can be performed in a simple dry or water bath [16]. LAMP is known for the specificity and simplicity; hence it would be an excellent tool for detecting an important sea-foodborne pathogen viz V. parahaemolyticus. In this study, we have optimized LAMP assay for the sensitive detection of pathogenic strains of $V$. parahaemolyticus in seafood without enrichment. The assay was validated by detecting the organism from a direct seafood sample and comparing it with existing molecular methods.

\section{Methods}

\section{Bacterial strains, culture condition, and genomic DNA}

Details of the bacterial strains used in this study are listed in Table ST1, which includes V. parahaemolyticus strains, other Vibrio, and non-Vibrio strains. All these bacterial strains were tested to determine the specificity of the LAMP assay. The strains of $V$. parahaemolyticus and other bacterial strains were revived from the institutional deep freezer $\left(-80{ }^{\circ} \mathrm{C}\right.$ ) (Thermo Scientific, USA) into $5 \mathrm{ml}$ of tryptic soy broth (TSB) (HiMedia, Mumbai, India) and incubated at $35 \pm 2{ }^{\circ} \mathrm{C}$ for $24 \mathrm{~h}$. The overnight grown V. parahaemolyticus culture was streaked onto a selective medium, thiosulfate-citrate-bile salts-sucrose (TCBS) agar (HiMedia,
India) obtain a single colony. Other bacterial strains were directly sub-cultured into $5 \mathrm{ml}$ Luria Bertani (LB) broth. Genomic DNA was extracted from all the cultures used in this study as per the protocol described by Ausubel et al. [17] with minor modifications. DNA concentration and purity were checked using a spectrophotometer (BioSpectrometer ${ }^{\circledR}$ basic, Eppendorf, USA).

\section{LAMP primers and assay optimization}

The $t d h$ and trh genes of $V$. parahaemolyticus were retrieved from NCBI GenBank (https://www.ncbi.nlm.nih.gov/ genbank/) database. The sequences were further subjected to multiple sequence alignment tools, multi-align (http:// multalin.toulouse.inra.fr/multalin/) [18] to find the consensus sequences. The best-matched sequence was chosen for primer designing. LAMP primer designing was done using PrimerExplorer software-V5 (Eiken Chemical Co. Ltd., Japan; http://primerexplorer.jp/e/).

The LAMP assay was optimized for the detection of $V$. parahaemolyticus targeting the $t r h$ and $t d h$ gene. LAMP assay was performed in a $25 \mu \mathrm{l}$ reaction mixture, containing $1 \times$ reaction mixtures (Eiken Chemical, Japan), template DNA (100 ng/ $\mu \mathrm{l}), 1 \mu \mathrm{l}$ of $B s t$ DNA polymerase (Eiken Chemical, Japan), and 40 pmol of FIP and BIP, 20 pmol of F3 and B3, for the amplification of $t d h$ gene 5 pmol of LF primer was used. Results were analyzed using LoopAmp real-time turbidimeter (LA-500, Eiken Japan) and 2\% agarose gel, stained with ethidium bromide $(0.5 \mu \mathrm{g} / \mathrm{ml})$ and analyzed using a gel documentation system (Bio-Rad, CA, USA). The reaction was carried out using a simple dry bath (Genei, India) and real-time turbidimeter at different temperatures $\left(60,63\right.$, and $\left.65^{\circ} \mathrm{C}\right)$ for 15,30 , and $60 \mathrm{~min}$, followed by inactivation at $80^{\circ} \mathrm{C}$ for $5 \mathrm{~min}$. Details of primers used in this study are listed in Table ST2.

\section{Specificity test of trh and tdh LAMP primers}

Various bacterial strains were used to test the specificity of LAMP assay. DNA extracted from the bacterial strains were subjected to both LAMP and conventional PCR amplification. The LAMP assay's specificity was determined by identifying the amplification of $t r h$ and $t d h$ genes in all the bacterial strains (Table ST1).

\section{Sensitivity of the LAMP assay}

\section{Determination of sensitivity using purified genomic DNA}

The sensitivity of LAMP assay was carried out by preparing a ten-fold serial dilution of DNA extracted from V. parahaemolyticus standard cultures (AQ4037 and 81TDH2 for $t r h^{+}$and $t d h^{+}$respectively) concentration ranging from $100 \mathrm{ng}$ to $1 \mathrm{fg}$. 
The LAMP outer primers, F3, and B3 were used for PCR amplifications to check the sensitivity.

\section{Determination of sensitivity in spiked clam meat}

The sensitivity of LAMP assay was also determined using clam meat spiked with $t d h^{+}$and $t r h^{+} V$. parahaemolyticus. The clam sample was purchased from a local market, Mangalore, India. Initially, the collected clam was pooled and homogenized in a sterile container. One gram of sample was taken and inoculated into $9 \mathrm{ml}$ of alkaline peptone water (APW). After $18 \mathrm{~h}$ of incubation, $1 \mathrm{ml}$ of the enriched sample was then taken in the micro-centrifuge tube and centrifuged at $900 \times g$ for $1 \mathrm{~min}$ to separate the larger meat particles. The supernatant was transferred in a fresh tube and centrifuged at $10,000 \times g$ for $10 \mathrm{~min}$. The pellet was gently mixed with $100 \mu \mathrm{l}$ of molecular grade water. The mixture was then heated at $95{ }^{\circ} \mathrm{C}$ for $5 \mathrm{~min}$ and immediately transferred into ice for $5 \mathrm{~min}$. Finally, centrifugation was performed at $2800 \times g$ for $5 \mathrm{~min}$, and crude cell lysate (CCL) was collected as supernatant in a fresh tube and preserved at $-20^{\circ} \mathrm{C}$ for future use. The CCL was used as DNA template and tested for the presence of $t d h$ and $t r h$ gene using PCR [19], and LAMP assay (protocol described before). Clam sample negative for conventional PCR \& LAMP assay was further used for the sensitivity study. The $t d h^{+}$and $t r h^{+} V$. parahaemolyticus cultures $\left(2.88 \times 10^{8}\right.$ and $2.35 \times 10^{8} \mathrm{CFU} / \mathrm{g}$ respectively) were serially diluted (ten-fold serial dilution). The $25 \mathrm{~g}$ of clam meat in $225 \mathrm{ml}$ of APW was homogenized separately using a high-speed blender. Then, $1 \mathrm{ml}$ from each different $V$. parahaemolyticus dilutions was inoculated to $9 \mathrm{ml}$ of homogenate, mixed, and immediately subjected for CCL preparation (protocol described before). One microliter of CCL was further used for conventional PCR, RT-PCR, and LAMP assay.

\section{LAMP assay to detect pathogenic $V$. parahaemolyticus in naturally contaminated samples}

Clam $(n=31)$ and shrimp $(n=31)$ were collected from the local market in March 2018 to February 2019 (Table 1). The samples were brought to the laboratory, cleaned, and homogenized aseptically in the laboratory. The CCL was prepared from the samples and subjected to LAMP assay targeting $t r h$ and $t d h$ genes. Similarly, the same CCL was also subjected to conventional PCR and RT-PCR assay.

\section{Comparison of LAMP assay with conventional PCR and RT-PCR for the detection of pathogenic $V$. parahaemolyticus}

\section{Conventional PCR assay}

Conventional PCR was carried out for all the seafood samples targeting $t r h$, and $t d h$ genes. The assay was performed in $30 \mu 1$ volumes comprising LAMP F3 and B3 primers and Tada et al. [19] primers using CCL. Amplification was done using a $\mathrm{T} 100^{\mathrm{TM}}$ thermal cycler (Bio-Rad, CA, USA) and visualized on $2 \%$ agarose gel and documented (described before).

\section{RT-PCR}

The RT-PCR assay was performed in a CFX96 real-time system (Bio-Rad, USA) for all the samples collected in the study. Reaction volume $(25 \mu \mathrm{l})$ (in triplicate) consists of the supermix (Bio-Rad, USA), 2.5 pmol of each forward and reverse primer of $t r h$ and $t d h$ genes (F3 and B3 of LAMP primers, Table ST2), and $2 \mu 1$ of crude DNA template. Amplification was performed with an initial denaturation at $95^{\circ} \mathrm{C}$ for $4 \mathrm{~min}$, followed by amplification for 40 cycles at $95{ }^{\circ} \mathrm{C}$ for $20 \mathrm{~s}$ and $55^{\circ} \mathrm{C}$ for $30 \mathrm{~s}$. Melt curve analysis to check the random amplification of untargeted regions from 65 to $95{ }^{\circ} \mathrm{C}$ for $5 \mathrm{~s}$ with an increase of $0.5^{\circ} \mathrm{C}$ in a stepwise manner as compared to a positive control $( \pm 0.5)$. A cycle threshold $(\mathrm{Ct})$ value of less than 35 was considered to be positive. A no-template control and positive control were included in every reaction. The amplification for various samples (Ct values of 24-35) was validated by considering the $\mathrm{Ct}$ value of positive control. Representative amplicons were also confirmed by being visualized on $2 \%$ agarose gel and documented (described before).

\section{Statistical analysis}

The significant difference between two detection methods, i.e., LAMP and conventional PCR and LAMP and RT-PCR for each gene were calculated using two-sample proportion tests with the significance of $p<0.05$. Two sample proportion tests are performed using an online software Mathcracker. Graphs were generated using Prism version 5.0 software (Graph Pad, Inc., La Jolla, USA). The percentage of agreement between three diagnostic assays was calculated using Cohen's Kappa coefficient in SPSS 16.0 software (SPSS Inc., Chicago, IL, USA). The kappa coefficients' values were interpreted according to the criteria of Viera and Garrett [20]. 
Table 1 Details of the samples and results of the LAMP, realtime PCR, and conventional PCR assay

\begin{tabular}{|c|c|c|c|c|c|c|c|c|c|}
\hline \multirow[t]{2}{*}{ Sl. no. } & \multirow[t]{2}{*}{ Sample type } & \multirow[t]{2}{*}{ Place } & \multirow[t]{2}{*}{ Culture ID } & \multicolumn{2}{|c|}{$\mathrm{PCR}^{\mathrm{a}}$} & \multicolumn{2}{|c|}{ RT-PCR ${ }^{a}$} & \multicolumn{2}{|c|}{$\begin{array}{l}\text { LAMP } \\
\text { assay }\end{array}$} \\
\hline & & & & trh & $t d h$ & trh & $t d h$ & trh & $t d h$ \\
\hline 1 & Clam & Kundhapur & SBCL0118/1 & - & - & - & - & - & - \\
\hline 2 & Clam & Kallapu & KCL0218/3 & - & - & + & - & - & - \\
\hline 3 & Clam & Thokkottu & THCL0218/4 & - & - & + & - & - & - \\
\hline 4 & Clam & Kuloor & KUCL0218/5 & - & - & - & - & - & - \\
\hline 5 & Clam & Tannirbhavi & TNCL0218/8 & - & - & - & - & - & - \\
\hline 6 & Clam & Ullal & UBCL0218/9 & - & - & - & - & - & - \\
\hline 7 & Clam & Kasargod & KSCL0318/10 & - & - & - & + & - & + \\
\hline 8 & Clam & Beeri Dakke & BDCL0318/11 & - & - & + & + & + & + \\
\hline 9 & Clam & Malpe & MKCL0318/12 & - & - & - & - & - & - \\
\hline 10 & Clam & Mulki & MMCL0318/13 & - & - & - & - & - & - \\
\hline 11 & Clam & Kannur & TKCL0318/14 & - & - & - & + & - & - \\
\hline 12 & Clam & Dakke, Mangaluru & CDCL0318/15 & - & - & - & + & + & + \\
\hline 13 & Clam & Kasaragod & KRCL0318/16 & - & - & - & - & - & - \\
\hline 14 & Clam & Kumbala & KMCL0318/17 & - & - & - & - & - & - \\
\hline 15 & Clam & Kannur & SWCL0318/18 & - & - & + & + & - & - \\
\hline 16 & Clam & Nethravathi & NBCL0318/19 & - & - & + & + & + & - \\
\hline 17 & Clam & Dakke, Mangaluru & ITCL0318/20 & - & - & + & + & - & - \\
\hline 18 & Clam & Kanhangad & SKCL0318/21 & - & - & - & - & - & - \\
\hline 19 & Clam & Dakke, Mangaluru & AMCL0318/22 & - & - & + & - & - & - \\
\hline 20 & Clam & Dakke, Mangaluru & EKCL0318/23 & - & - & + & - & - & - \\
\hline 21 & Clam & Kasaragod & UKCL0418/25 & - & - & + & - & - & - \\
\hline 22 & Clam & Mulki & CECL0418/26 & - & - & + & - & - & - \\
\hline 23 & Clam & Kanhangad & NICL0418/27 & - & - & - & - & - & - \\
\hline 24 & Clam & Kannur & TRCL0418/28 & - & - & - & - & - & - \\
\hline 25 & Clam & Kuppepadav & JSCL0418/29 & - & - & - & - & + & - \\
\hline 26 & Clam & Malpe & ZYCL0418/30 & - & - & - & - & - & - \\
\hline 27 & Clam & Mulki & MUCL0118/2 & - & - & + & - & - & - \\
\hline 28 & Clam & Kannur & KACL0218/6 & - & - & - & - & - & - \\
\hline 29 & Clam & Dakke & DHCL0218/7 & - & - & - & - & - & - \\
\hline 30 & Clam & Surathkal & PRCL0418/24 & - & - & + & - & - & - \\
\hline 31 & Clam & Thumbe & BLCL0418/34 & - & - & - & - & + & - \\
\hline 32 & Shrimp & Thokottu & SHT121118 & - & - & + & + & + & + \\
\hline 33 & Shrimp & Statebank, Mangaluru & SHSB131118 & - & + & - & - & - & - \\
\hline 34 & Shrimp & Kasaragod & SHKG131118 & - & - & - & - & - & - \\
\hline 35 & Shrimp & Beeri & SHBM131118 & - & - & - & + & - & - \\
\hline 36 & Shrimp & Deralakatte & SHD151118 & - & - & - & - & - & - \\
\hline 37 & Shrimp & Beeri & SHBI151118 & - & - & - & - & - & - \\
\hline 38 & Shrimp & Kumbala & SHKU151118 & - & - & - & - & + & + \\
\hline 39 & Shrimp & Mulki & SHMU211118 & - & - & - & - & - & + \\
\hline 40 & Shrimp & Deralakatte & SHDR211118 & - & - & + & - & + & + \\
\hline 41 & Shrimp & Kuttar & SHKU211118 & - & - & - & - & - & - \\
\hline 42 & Shrimp & Thokottu & SHTH211118 & - & - & - & - & - & - \\
\hline 43 & Shrimp & Ullala & SHUL231118 & - & - & - & - & - & - \\
\hline 44 & Shrimp & Deralakatte & SHDR231118 & - & - & - & - & - & - \\
\hline 45 & Shrimp & Kuttar & SHKR231118 & - & - & - & - & - & - \\
\hline 46 & Shrimp & Thokottu & TOSH051218 & - & - & - & - & - & - \\
\hline 47 & Shrimp & Deralakatte & DLSH051218 & - & - & - & + & - & - \\
\hline 48 & Shrimp & Deralakatte & SHDT171218A & - & - & - & - & - & - \\
\hline 49 & Shrimp & Deralakatte & SHDT171218B & - & - & - & - & - & - \\
\hline
\end{tabular}


Table 1 (continued)

\begin{tabular}{|c|c|c|c|c|c|c|c|c|c|}
\hline \multirow[t]{2}{*}{ Sl. no. } & \multirow[t]{2}{*}{ Sample type } & \multirow[t]{2}{*}{ Place } & \multirow[t]{2}{*}{ Culture ID } & \multicolumn{2}{|c|}{$\mathrm{PCR}^{\mathrm{a}}$} & \multicolumn{2}{|c|}{ RT-PCR ${ }^{\mathrm{a}}$} & \multicolumn{2}{|c|}{$\begin{array}{l}\text { LAMP } \\
\text { assay }\end{array}$} \\
\hline & & & & trh & $t d h$ & trh & $t d h$ & trh & $t d h$ \\
\hline 50 & Shrimp & Thokottu & SHTT171218 & - & - & - & - & - & - \\
\hline 51 & Shrimp & Thokottu & SHTK191218 & - & - & - & - & - & - \\
\hline 52 & Shrimp & Ullala & SHYK191218 & - & - & - & + & - & - \\
\hline 53 & Shrimp & Manjeshwar & SHMA191218 & - & - & - & - & - & - \\
\hline 54 & Shrimp & Kasaragod & SHKS191218 & - & - & - & - & - & - \\
\hline 55 & Shrimp & Manjeshwar & MJSH060219 & - & - & - & - & - & - \\
\hline 56 & Shrimp & Dakke, Mangaluru & DKSH060219 & - & - & - & + & - & - \\
\hline 57 & Shrimp & Ullala & UASH080219 & - & - & - & - & - & - \\
\hline 58 & Shrimp & Thokottu & TUSH080219 & - & - & - & + & - & - \\
\hline 59 & Shrimp & Statebank, Mangaluru & SBSH110219 & - & - & + & - & - & - \\
\hline 60 & Shrimp & Dakke, Mangaluru & DESH110219 & - & - & - & - & - & - \\
\hline 61 & Shrimp & Statebank, Mangalore & SBSH150219 & - & - & - & - & - & - \\
\hline 62 & Shrimp & Deralakatte & DLSH150219 & - & - & - & + & - & - \\
\hline
\end{tabular}

(+): Positive, (-): Negative

${ }^{\mathrm{a}} \mathrm{PCR}$ and RT-PCR were performed using F3 and B3 primers

\section{Result and discussion}

\section{Specificity and sensitivity of LAMP assay}

In LAMP assay, $63{ }^{\circ} \mathrm{C}$ temperatures for $60 \mathrm{~min}$ of amplification was found to be optimum for both $t d h$ and $t r h$ genes. An increase in the turbidity due to LAMP reaction was measured using LoopAmp real-time turbidimeter as compared to negative controls. The reaction was considered positive when turbidity reached 0.1 within $60 \mathrm{~min}$ (Fig. SF1). Specificity assay of LAMP assay was tested using various bacterial strains, including both $V$. parahaemolyticus and other bacterial strains. Both the designed primers of $t r h$ and $t d h$ genes showed good specificity with no false positive and negative results for the tested bacterial isolates (Fig. SF2). In general, the presence of $t d h$ and/or trh is primarily associated with the pathogenic strains of $V$. parahaemolyticus and is considered a virulence marker $[1,2,21]$. It is also true that the presence of $t d h$ or $t r h$ genes have been reported in other non- $V$. parahaemolyticus vibrionaceae species, including $V$. mimicus, V. cholerae, V. hollisae, V. diaboilcus, and $V$. alginolyticus [1]. Hence, further inclusion of these strains harboring $t d h$ or $t r h$ can confirm the assay's high specificity. However, due to these strains' unavailability, we could not include them during our specificity study.

The sensitivity of LAMP assay was found to be high. In the DNA dilution method, LAMP assay was able to detect $1 \mathrm{pg}$ of DNA ( $t r h$ and $t d h$ ), whereas conventional PCR was able to detect 100 pg of DNA (Fig. SF3). Similarly, when the sensitivity of the assay was tested with spiked clam meat, it was able to detect $10^{2} \mathrm{CFU} / \mathrm{g}$ (1 CFU per reaction) and $10^{4} \mathrm{CFU} / \mathrm{g}$ (100 CFU per reaction) by LAMP and conventional PCR assay, respectively. The RT-PCR assay showed a similar degree of sensitivity of LAMP assay with a detection limit of $10^{2} \mathrm{CFU} / \mathrm{g}$ (Fig. 1). Di et al. [22] developed LAMP assay targeting $t h$ and $t d h$, which could able to detect as low as $2 \mathrm{CFU} / \mathrm{g}$ of $V$. parahaemolyticus in seafood. Prompamorn et al. [23] reported the detection limit of $10^{3} \mathrm{CFU} / \mathrm{g}$ for $V$. parahaemolyticus in spiked samples. LAMP assays with both loop primers can detect the target cells at concentration of $10 \mathrm{CFU}$ per reaction [24]. Previously, LAMP assay was developed for $t d h$ and $t r h$ to detect pathogenic strains of $V$. parahaemolyticus however, not been tested using seafood samples $[2,25,26]$. To date, all the LAMP-based assays developed for the detection of pathogenic $V$. parahaemolyticus targeting $t r h$ and $t d h$ was not validated by direct seafood samples, and the studies involved either enrichment or use of pure cultures. The other available isothermal amplification methods for the detection of $V$. parahaemolyticus require enrichment for detecting $2 \mathrm{CFU} / \mathrm{g}$ of cells in the seafood sample [27]. The validation of an assay is important to confirm the sensitivity, specificity, and accuracy of the method. Therefore, in this study, we have tested the optimized LAMP assay using clam and shrimp samples collected from the local market for 1 year.

\section{Detection of V. parahaemolyticus in naturally contaminated seafood sample}

Reports on the presence of $t r h$ and $t d h$ gene in environmental samples are always checked using conventional culturebased methods or standard conventional PCR based assays. The detection limit using these available methods is affected by low amount of template DNA, inhibitory agents present 

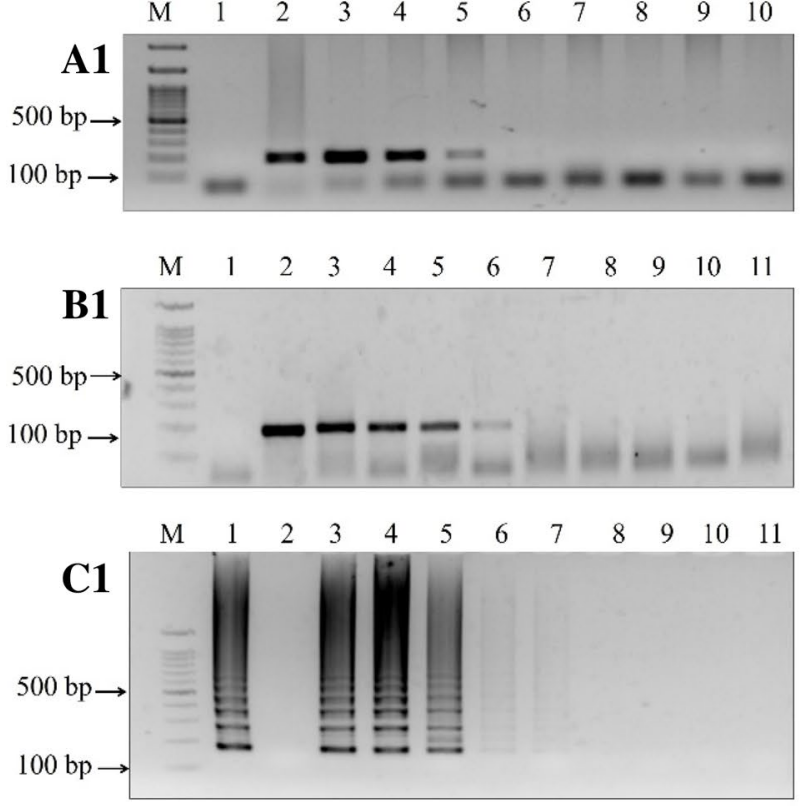

D1

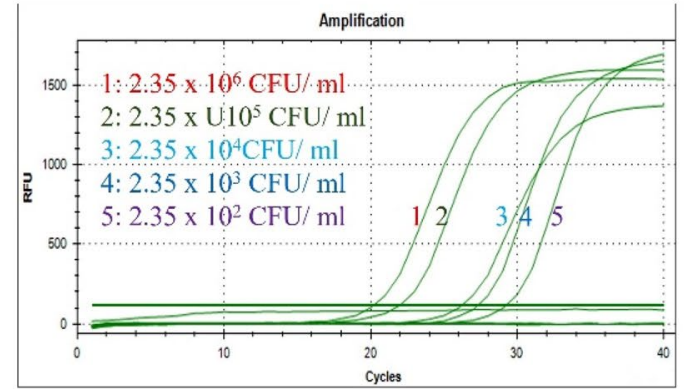

Fig. 1 Determination of sensitivity test by artificial contamination of clam targeting $t r h^{+}$and $t d h^{+} V$. parahaemolyticus culture. (A1, B1) Conventional PCR amplification targeting trh using Tada et al. [19] and F3-B3. Lane M: 100 bp marker, Lane 1: Negative control, Lane 2: Positive control: $2.35 \times 10^{7} \mathrm{CFU} / \mathrm{ml}$. Lanes 3-9: Reaction carried out with spiked suspensions containing $10^{6}$, to $0 \mathrm{CFU} / \mathrm{ml}$ cells. (A2, B2) Conventional PCR amplification targeting $t d h$ using Tada et al. [19] and F3-B3. Lane M: 100 bp marker, Lane 1: Negative control,

in the sample to perform conventional PCR [28]. Hence, the report of low prevalence may be due to the false-negative results by the tool used to detect the pathogenic strains of V. parahaemolyticus. Malcolm et al. [21] reported better LAMP assay sensitivity for the detection of $V$. parahaemolyticus over multiplex PCR, even when the targeted contaminant density was low in shellfish.

In this study, out of 62 samples screened (clam and shrimp), eight (12.9\%) were positive for trh, and seven (11.29\%) samples for $t d h$ gene by LAMP assay (Fig. SF4, Table 1). Five (8.02\%) samples were positive for both $t r h$ and $t d h$. However, three (4.83\%) samples were positive for $t r h$, and two (3.22\%) samples were positive for $t d h$ gene. The increase in the pathogenic strains of $V$. parahaemolyticus in the food chain is possibly due to cross-contamination in
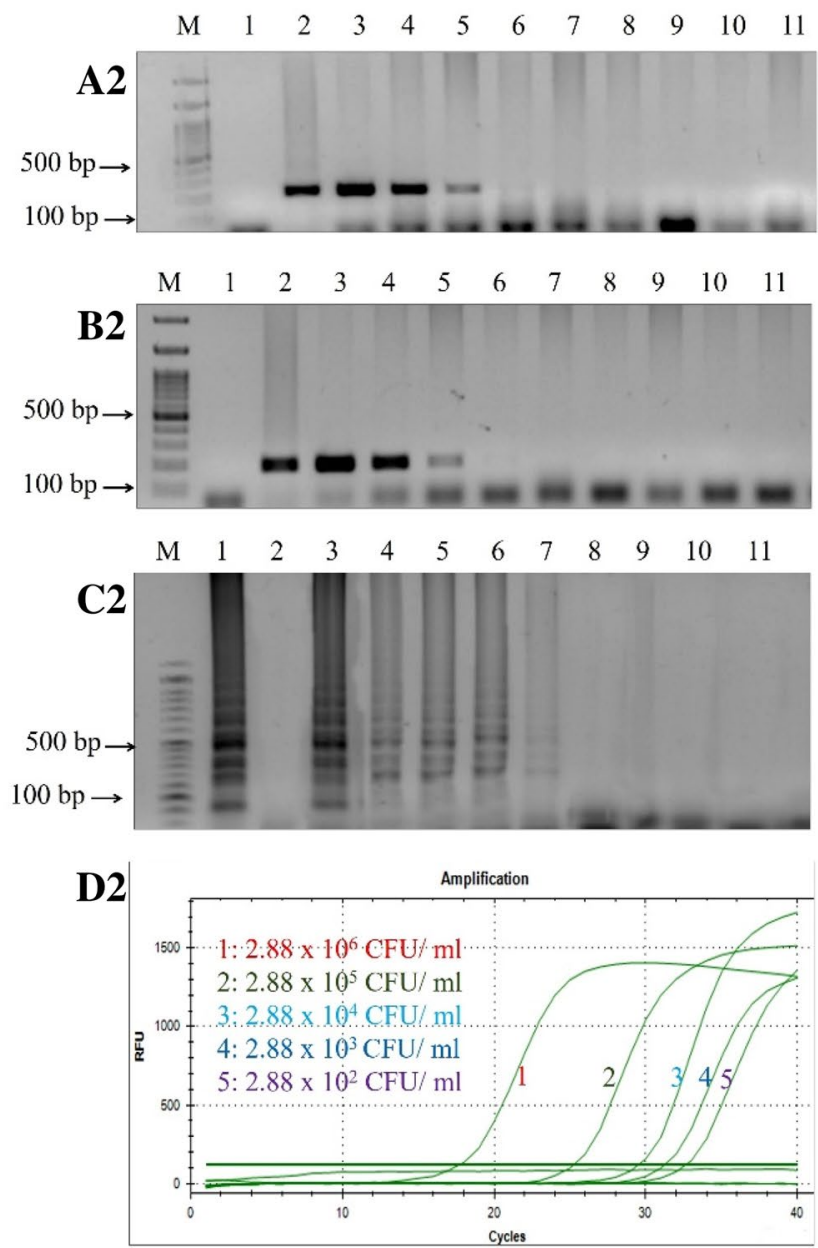

Lane 2: Positive control: $2.88 \times 10^{7} \mathrm{CFU} / \mathrm{ml}$. Lanes 3-9: Reaction carried out with spiked suspensions containing $10^{6}$, to $0 \mathrm{CFU} / \mathrm{ml}$ cells. (C1, C2) LAMP amplification targeting $t r h$ and $t d h$. Lane M: 100 bp marker, Lane 1: Positive control (trh: $2.35 \times 10^{7} \mathrm{CFU} / \mathrm{ml}$ and $\left.t d h: 2.88 \times 10^{7} \mathrm{CFU} / \mathrm{ml}\right)$, Lane 2: Negative control, Lanes 3-9: Reaction carried out with spiked suspensions containing $10^{6}$, to $0 \mathrm{CFU} / \mathrm{ml}$ cells. (D1, D2) Results of RT-PCR showing sensitivity for $t r h$ and $t d h$ (F3 and B3) in the spiked sample

the seafood harvesting, processing and distributing centers, and changing cooking habits. Hence, these issues need to be addressed, and simple detection methods required to be implemented. A similar result was also observed by Raghunath et al. [29] where the number of $t r h^{+} V$. parahaemolyticus was significantly higher in seafood samples as compared to $t d h^{+} V$. parahaemolyticus.

In different types of seafood samples, six (19.35\%) clam, and four shrimp (12.9\%) samples were carrying pathogenicity associated genes $(t r h / t d h)$. Further, LAMP assay detected the presence of $t r h$ gene in five $(16.12 \%)$ clam and three $(9.6 \%)$ shrimp samples. $t d h$ gene was detected in three (9.6\%) clam samples and four (12.9\%) shrimp samples. Odeyemi [7] reported a meta-analysis of the incidence of V. parahaemolyticus from 2003 to 2015, which showed that 


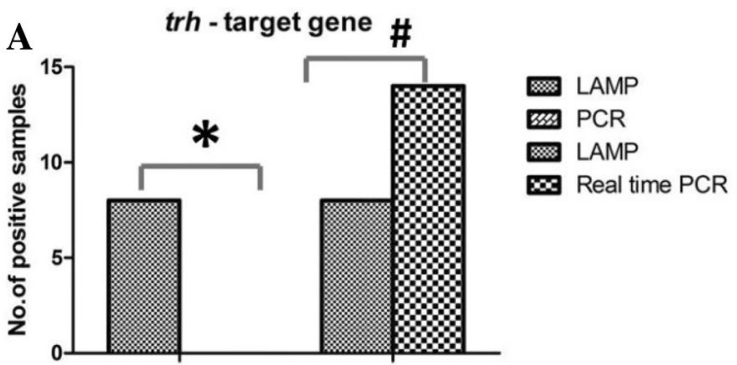

Detection techniques

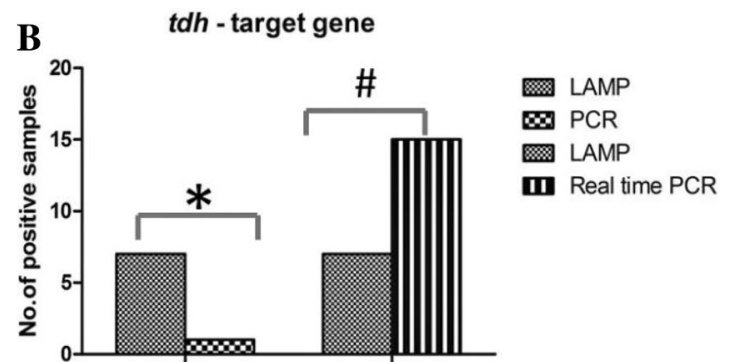

Detection techniques

Fig. 2 Comparison between LAMP, conventional PCR assay, and RT-PCR of $t r h$ gene (a) and $t d h$ gene (b). *Significant difference between LAMP and conventional PCR assay $(p<0.05) .{ }^{*}$ No significant difference between LAMP and real-time PCR assay

the prevalence of $V$. parahaemolyticus was $52.9 \%$ for clam and $48.3 \%$ for shrimp. Besides, other studies also prove the fact that $V$. parahaemolyticus prevalence is relatively more in shellfish [30, 31].

\section{Comparison of LAMP assay with conventional PCR and RT-PCR}

None of the seafood samples were positive for trh gene in conventional PCR assay, and only one sample (1.6\%) was positive for $t d h$ gene. This is possibly due to CCL as a template for conventional PCR. Reports suggest that PCR amplification can be affected due to the presence of inhibitors in the reaction mix. However, this is not a major issue for LAMP assay since it is based on $b s t$ polymerase enzyme [32, 33]. In the RT-PCR assay, 15 (24.19\%) samples were positive for $t r h$, and 14 (22.58\%) samples were positive for $t d h$ genes (Fig. 2, Table 1). Results were analyzed using a twosample proportion test to check the significant difference between the techniques compared in the study. A significant difference $(p<0.05)$ in the results was observed when samples were subjected to LAMP and conventional PCR for the detection of two different genes ( $t r h$ and $t d h$ ). However, no significant difference was observed when LAMP and RTPCR were used to detect $V$. parahaemolyticus using trh and $t d h$ genes. Cao et al. [34] explained the equal sensitivity of LAMP and RT-PCR for the detection of viable but nonculturable (VBNC) V. parahaemolyticus. The agreement between LAMP and RT-PCR analysis was found to be fair with kappa value $k \geq 0.2$ for both the genes. There was no agreement between LAMP and PCR with kappa value $k \leq 0$. Samples showing positive amplification in LAMP, RT-PCR, and PCR methods are represented in the Venn diagram (Fig. SF5). Even though the RT-PCR (cutoff $\mathrm{Ct}$ value $\leq 35$ ) was able to amplify $t d h$ and $t r h$ genes in slightly more samples than LAMP assay, LAMP assay can be considered to be a better practical method to detect pathogenic strains of $V$. parahaemolyticus due to its simplicity and cost-effectiveness.
Acknowledgements This study was financially supported by the Department of Biotechnology, Government of India, through the project (BT/PR12230/AAQ/3/698/2014) and Nitte (Deemed to be University), Mangalore, India, through an intramural research grant (NUFR2/2018/10/25).

Author contributions KPA designed the study, collected samples, performed the experiments, analyzed result data, and prepared the initial draft of the manuscript. AN carried out laboratory experiments and reviewed the manuscript. IK and IK supervised the study and revised the manuscript. BM conceptualized and designed the study, analyzed result data, supervised the study, mobilized the resource, and finalized the manuscript. All authors read and approved the final manuscript.

\section{Compliance with ethical standards}

Conflict of interest The authors declare that there is no conflict of interest.

\section{References}

1. Raghunath P (2015) Roles of thermostable direct hemolysin (TDH) and TDH-related hemolysin (TRH) in Vibrio parahaemolyticus. Front Microbiol 5:2010-2013

2. Zhao X, Wang L, Chu J, Li Y, Li Y, Xu Z, Li L, Shirtliff ME, He X, Liu Y, Wang J, Yang L (2010) Rapid detection of Vibrio parahaemolyticus strains and virulent factors by loop-mediated isothermal amplification assays. Food Sci Biotechnol 19:1191-1197

3. Nishibuchi M, Fasano A, Russell RG, Kaper JB (1992) Enterotoxigenicity of Vibrio parahaemolyticus with and without genes encoding thermostable direct hemolysin. Infect Immun 60:3539-3545

4. Ceccarelli D, Hasan NA, Huq A, Colwell RR (2013) Distribution and dynamics of epidemic and pandemic Vibrio parahaemolyticus virulence factors. Front Cell Infect Microbiol 3:1-9

5. Letchumanan V, Chan KG, Lee LH (2014) Vibrio parahaemolyticus: a review on the pathogenesis, prevalence, and advance molecular identification techniques. Front Microbiol 5:1-13

6. Liu M, Chen S (2015) A novel adhesive factor contributing to the virulence of Vibrio parahaemolyticus. Sci Rep 5:1-10

7. Odeyemi OA (2016) Incidence and prevalence of Vibrio parahaemolyticus in seafood: a systematic review and meta-analysis. Springerplus 5:464 
8. Centers for Disease Control and Prevention (CDC) (2019) Vibrio species causing vibriosis. Available at https://www.cdc.gov/vibri o/faq.html

9. Nair GB, Ramamurthy T, Bhattacharya SK, Dutta B, Takeda Y, Sack DA (2007) Global dissemination of Vibrio parahaemolyticus serotype O3:K6 and its serovariants. Clin Microbiol Rev 20:39-48

10. Gong P, Zhang T, Chen F, Wang L, Jin S, Bai X (2014) Advances in loop-mediated isothermal amplification: Integrated with several point-of-care diagnostic methods. Anal Methods 6:7585-7589

11. Niessen L (2015) Current state and future perspectives of loopmediated isothermal amplification (LAMP)-based diagnosis of filamentous fungi and yeasts. Appl Microbiol Biotechnol 99:553-574

12. Gürtler C, Laible M, Schwabe W, Steinhäuser H, Li X (2018) How to transfer a quantitative molecular diagnostic test to multiple qPCR platforms. J Mol Diagn 20:398-414

13. Karunasagar I, Maiti B, Kumar BK (2018) Molecular methods to study Vibrio parahaemolyticus and Vibrio vulnificus from atypical environments. In: Methods in microbiology, 1st edn. Elsevier Ltd., Amsterdam

14. Lei S, Gu X, Zhong Q, Duan L, Zhou A (2020) Absolute quantification of Vibrio parahaemolyticus by multiplex droplet digital PCR for simultaneous detection of $t l h, t d h$ and $u r e R$ based on single intact cell. Food Control 114:107207

15. World Health Organization (WHO) (2016) The use of loop-mediated isothermal amplification (TB-LAMP) for the diagnosis of pulmonary tuberculosis: policy guidance. https://www.who.int/ tb/publications/lamp-diagnosis-molecular/en/

16. Anupama KP, Chakraborty A, Karunasagar I, Karunasagar I, Maiti B (2019) Loop-mediated isothermal amplification assay as a point-of-care diagnostic tool for Vibrio parahaemolyticus: recent developments and improvements. Expert Rev Mol Diagn 19:229-239

17. Ausubel FM, Brent R, Kingston RE, Moore DD, Seidman JG, Smith JA, Struhl K (1995) A compendium of methods from current protocols in molecular biology, 3rd edn. John Wiley \& Sons, New York

18. Corpet $F$ (1988) Multiple sequence alignment with hierarchical clustering. Nucleic Acids Res 16:10881-10890

19. Tada J, Ohashi T, Nishimura N, Shirasaki Y, Ozaki H, Fukushima S, Takano J, Nishibuchi M (1992) Detection of the thermostable direct hemolysin gene $(t d h)$ and the thermostable direct hemolysin-related hemolysin gene (trh) of Vibrio parahaemolyticus by polymerase chain reaction. Mol Cell Probes 6:477-487

20. Viera AJ, Garrett JM (2005) Understanding interobserver agreement: the kappa statistic. Fam Med 37:360-363

21. Malcolm TT, Cheah YK, Radzi CW, Kasim FA, Kantilal HK, John TY, Martinez Urtaza J, Nakaguchi Y, Nishibuchi M, Son R (2015) Detection and quantification of pathogenic Vibrio parahaemolyticus in shellfish by using multiplex PCR and loop-mediated isothermal amplification assay. Food Control 47:664-671

22. Di H, Ye L, Neogi SB, Meng H, Yan H, Yamasaki S, Shi L (2015) Development and evaluation of a loop-mediated isothermal amplification assay combined with enrichment culture for rapid detection of very low numbers of Vibrio parahaemolyticus in seafood samples. Biol Pharm Bull 38:82-87

23. Prompamorn $\mathrm{P}$, Sithigorngul $\mathrm{P}$, Rukpratanporn S, Longyant $\mathrm{S}$, Sridulyakul P, Chaivisuthangkura P (2011) The development of loop-mediated isothermal amplification combined with lateral flow dipstick for detection of Vibrio parahaemolyticus. Lett Appl Microbiol 52:344-351

24. Yamazaki W, Kumeda Y, Misawa N, Nakaguchi Y, Nishibuchi M (2010) Development of a loop-mediated isothermal amplification assay for sensitive and rapid detection of the $t d h$ and $t r h$ genes of Vibrio parahaemolyticus and related vibrio species. Appl Environ Microbiol 76:820-828
25. Yamazaki W, Kumeda Y, Uemura R, Misawa N (2011) Evaluation of a loop-mediated isothermal amplification assay for rapid and simple detection of Vibrio parahaemolyticus in naturally contaminated seafood samples. Food Microbiol 28:1238-1241

26. Nemoto J, Ikedo M, Kojima T, Momoda T, Konuma H, HaraKudo Y (2011) Development and evaluation of a loop-mediated isothermal amplification assay for rapid and sensitive detection of Vibrio parahaemolyticus. J Food Prot 74:1462-1467

27. Jiang W, Ren Y, Han X, Xue J, Shan T, Chen Z, Liu Y, Wang Q (2020) Recombinase polymerase amplification-lateral flow (RPA-LF) assay combined with immunomagnetic separation for rapid visual detection of Vibrio parahaemolyticus in raw oysters. Anal Bioanal Chem 412:2903-2914

28. Di Pinto A, Terio V, Di Pinto P, Colao V, Tantillo G (2012) Detection of Vibrio parahaemolyticus in shellfish using polymerase chain reaction-enzyme-linked immunosorbent assay. Lett Appl Microbiol 54:494-498

29. Raghunath P, Karunasagar I, Karunasagar I (2009) Improved isolation and detection of pathogenic Vibrio parahaemolyticus from seafood using a new enrichment broth. Int J Food Microbiol 129:200-203

30. Nakaguchi Y (2013) Contamination with Vibrio parahaemolyticus and its virulent strains in seafood marketed in Thailand, Vietnam, Malaysia, and Indonesia from 2008 to 2011. Tropical Med Int Health 3:95-102

31. Tran TH, Yanagawa H, Nguyen KT, Hara-Kudo Y, Taniguchi T, Hayashidani H (2018) Prevalence of Vibrio parahaemolyticus in seafood and water environment in the Mekong Delta, Vietnam. J Vet Med Sci 11:1737-1742

32. Poon LL, Wong BW, Ma EH, Chan KH, Chow LM, Abeyewickreme W, Tangpukdee N, Yuen KY, Guan Y, Looareesuwan S, Peiris JM (2006) Sensitive and inexpensive molecular test for falciparum malaria: detecting Plasmodium falciparum DNA directly from heat-treated blood by loop-mediated isothermal amplification. Clin Chem 52:303-306

33. Inácio J, Flores O, Spencer-Martins I (2008) Efficient identification of clinically relevant Candida yeast species by use of an assay combining panfungal loop-mediated isothermal DNA amplification with hybridization to species-specific oligonucleotide probes. J Clin Microbiol 46:713-720

34. Cao X, Zhao L, Zhang J, Chen X, Shi L, Fang X, Xie H, Chang Y, Wang L (2019) Detection of viable but nonculturable Vibrio parahaemolyticus in shrimp samples using improved real-time PCR and real-time LAMP methods. Food Control 103:145-152

35. Suresh S, Karanth PA, Alva PP, Akash SK, Maiti B, Karunasagar I, Karunasagar I, Premanath R (2019) Diabetic foot ulcer caused by Vibrio parahaemolyticus: two case reports. Clin Microbiol Newsl 41:101-102

36. D'Souza C, Prabhakar Alva P, Karanth Padyana A, Karunasagar I, Karunasagar I, Kumar BK (2019) Unveiling the acid stress response of clinical genotype Vibrio vulnificus isolated from the marine environments of Mangaluru coast, India. Can J Microbiol 65:681-690

37. Maiti B, Raghunath P, Karunasagar I, Karunasagar I (2009) Cloning and expression of an outer membrane protein OmpW of Aeromonas hydrophila and study of its distribution in Aeromonas spp. J Appl Microbiol 107:1157-1167

38. Deekshit VK, Kumar BK, Rai P, Srikumar S, Karunasagar I, Karunasagar I (2012) Detection of class 1 integrons in Salmonella Weltevreden and silent antibiotic resistance genes in some seafood-associated nontyphoidal isolates of Salmonella in south-west coast of India. J Appl Microbiol 112:1113-1122

Publisher's Note Springer Nature remains neutral with regard to jurisdictional claims in published maps and institutional affiliations. 